University of Nebraska - Lincoln

DigitalCommons@University of Nebraska - Lincoln

Publications from USDA-ARS / UNL Faculty

U.S. Department of Agriculture: Agricultural

Research Service, Lincoln, Nebraska

2011

Dehydration of Pollock Skin Prior to Gelatin Production

Cindy K. Bower

USDA Agricultural Research Service, Cindy.Bower@ars.usda.gov

Roberto J. Avena-Bustillos

USDA-ARS

Katie A. Hietala

USDA-ARS

Cristina Bilbao-Sainz

USDA-ARS

Carl W. Olsen

USDA-ARS

See next page for additional authors

Follow this and additional works at: https://digitalcommons.unl.edu/usdaarsfacpub

Part of the Agricultural Science Commons

Bower, Cindy K.; Avena-Bustillos, Roberto J.; Hietala, Katie A.; Bilbao-Sainz, Cristina; Olsen, Carl W.; and McHugh, Tara H., "Dehydration of Pollock Skin Prior to Gelatin Production" (2011). Publications from USDA-ARS / UNL Faculty. 554.

https://digitalcommons.unl.edu/usdaarsfacpub/554

This Article is brought to you for free and open access by the U.S. Department of Agriculture: Agricultural Research Service, Lincoln, Nebraska at DigitalCommons@University of Nebraska - Lincoln. It has been accepted for inclusion in Publications from USDA-ARS / UNL Faculty by an authorized administrator of DigitalCommons@University of Nebraska - Lincoln. 


\section{Authors}

Cindy K. Bower, Roberto J. Avena-Bustillos, Katie A. Hietala, Cristina Bilbao-Sainz, Carl W. Olsen, and Tara H. McHugh 


\title{
Dehydration of Pollock Skin Prior to Gelatin Production
}

\author{
Cindy K. Bower, Roberto J. Avena-Bustillos, Katie A. Hietala, \\ Cristina Bilbao-Sainz, Carl W. Olsen, and Tara H. McHugh
}

\begin{abstract}
Alaska pollock (Theragra chalcogramma) is the U.S.A.'s largest commercial fishery, with an annual catch of over 1 million tons. During pollock processing, the skins are discarded or made into fish meal, despite their value for gelatin production. The absence of gelatin-processing facilities in Alaska necessitates drying of the skins before transport to decrease the moisture content, but conventional hot-air drying is expensive. This study evaluated a less energy-intensive technology, the use of desiccants for reducing water weight in pollock skins prior to shipment. To ensure that the functional properties of gelatin obtained from dried pollock skins were not affected during desiccation, gelatins were prepared from each skin-drying treatment and compared with gelatin extracted from air-dried pollock skins. None of the desiccation treatments decreased the gel strength of pollock skin gelatin, nor were there major differences in gelling temperature or viscosity among the gelatin solutions. This suggests that pollock skins can be economically stabilized for transport to a gelatin-processing facility through the use of regenerable desiccants that are already common in the food industry.

Practical Application: Pollock skins destined for gelatin production can be stabilized using chemical desiccants prior to shipment. The dehydration process does not harm the functional properties of gelatin, such as gel strength, gelling temperature, and viscosity. This research suggests that fish skins can be economically stabilized for transport to a gelatin-processing facility through the use of regenerable desiccants that are already common in the food industry.

Keywords: dehydration, desiccants, fish-skin, gelatin, pollock
\end{abstract}

\section{Introduction}

$\mathrm{F}$ ish skins are composed of collagen, which can be hydrolyzed into gelatin through mild heat denaturation (Karim and Bhat 2009). Gelatins made from cold-water fish skins such as pollock differ from warm-water fish species in several important properties, including gel-set temperature. When these gels are cast as edible films, some favorable mechanical and barrier properties were observed (Giménez and others 2005; Avena-Bustillos and others 2006; Gómez-Guillén and others 2009). Although gelatins extracted from bovine and porcine hides are more common, there exists a global demand for fish-skin gelatin, especially in markets where religious dietary restrictions prohibit consumption of gelatin derived from mammals.

In Alaska, skins from pollock are considered to be a processing waste, despite studies that demonstrate their value for production of gelatin gels and films (Avena-Bustillos and others 2006; Bower and others 2006; Chiou and others 2008). Commercial manufacturers have expressed interest in Alaska pollock skins as a source of collagen for gelatin production, but have been reticent to utilize this ample supply due to high transportation costs and refrigeration necessary to preserve the skins during transit. Discovery of an economical method for stabilization of pollock skins would benefit both fish processors and the gelatin industry, especially if it also decreases the water content of the skins.

MS 20090982 Submitted 10/2/2009, Accepted 2/13/2010. Authors Bower and Hietala are with USDA Agricultural Research Service, Subarctic Agricultural Research Unit, PO Box 757200, Fairbanks, AK 99775-7200, U.S.A. Authors Avena-Bustillos, Bilbao-Sainz, Olsen, and McHugh are with USDA/ARS, Western Regional Research Center, 800 Buchanan St., Albany, CA 94710, U.S.A. Direct inquiries to author Bower (E-mail: Cindy.Bower@ ars.usda.gov).
There are a variety of techniques for stabilizing perishable fish tissues, none of which, however, are specific to fish skin. Smoking (Sikorski and Kałodziejska 2002), marinating (Gokoglu and others 2003), and fermenting (Dapkevicius and others 2000) are traditional methods of inhibiting spoilage in fish. However, these techniques may not sufficiently decrease the water content, thereby necessitating a secondary measure to ensure complete stabilization. Solar drying is an ancient method for preserving foods, but this is a slow process that is highly dependent upon ambient temperature and humidity (Reza and others 2009). Salting with sodium chloride has also proven to be an effective method for reducing water weight by diffusing salts into the skin matrix and causing water to flow out (Wang and others 2000). Another chemical option for dehydrating fish tissues is desiccation by using other compounds that adsorb moisture.

Little information is available about the practice of placing desiccants in direct contact with foods to decrease moisture content. Calcium bentonite was successfully placed in contact with grains such as corn for drying (Graham and Bilanski 1986), but the method has apparently never been extended to fish. Reducing the water content of pollock skins by applying desiccants commonly used in the food industry would decrease transportation costs during shipment to a gelatin processing facility. Further economic benefits would be gained if the desiccants were regenerable and therefore capable of repeated use. However, placing chemical agents in direct contact with fish skins may negatively affect the yield or quality of gelatin produced from the skins.

The objective of this study was to investigate the use of desiccants to reduce water weight in pollock skins without damaging the conversion of collagen to high-quality gelatin and without affecting the functional properties of the resultant gels and films. 


\section{Materials and Methods}

\section{Gelatin}

Pollock skins were obtained from a commercial fish-processing plant in Kodiak Alaska and were processed into gelatin according to the procedure of Avena-Bustillos and others (2006). Briefly, fish skins were washed, first in iced water $\left(1: 6, \mathrm{w} / \mathrm{v} ; 10 \mathrm{~min} 2{ }^{\circ} \mathrm{C}\right)$, then in salt water $\left(0.8 \mathrm{~N} \mathrm{NaCl} ; 1: 6, \mathrm{w} / \mathrm{v} ; 4^{\circ} \mathrm{C}\right)$ for muscle protein solubilization. Washed skins were stirred with cold $0.2 \mathrm{~N} \mathrm{NaOH}(1: 6$, $\mathrm{w} / \mathrm{v} ; 40 \mathrm{~min}$ ) for fish skin swelling and loss of amide-nitrogen, then drained and stirred with $0.2 \mathrm{~N}$ sulfuric acid using the same conditions. Samples were drained and rinsed with iced tap water after each step. Skins were then treated with $0.7 \%$ citric acid (1:6, w/v; $40 \mathrm{~min}$ ), rinsed with iced tap water, and dissolved overnight with distilled water $45^{\circ} \mathrm{C}$. Gelatin solutions $(6.67 \%[\mathrm{w} / \mathrm{w}]$ gelatin in water) were prepared by heating $\left(60^{\circ} \mathrm{C}, 1 \mathrm{~h}\right)$ following the procedure of Avena-Bustillos and others (2006). The $\mathrm{pH}$ of each gelatin solution was measured at $21^{\circ} \mathrm{C}$ using an Accumet $\mathrm{pH}$ meter (Fisher Scientific, Pittsburgh, Pa., U.S.A.). Gel clarity was measured as percentage of transmittance $\left(600 \mathrm{~nm}, 21^{\circ} \mathrm{C}\right)$ using a SpectroMax Plus microplate spectrophotometer (Molecular Devices, Union City, Calif., U.S.A.). Gelatin films were cast by pouring gel solutions onto a flat Mylar surface and spreading to uniform thickness using a stainless steel drawdown bar with a $2.0-\mathrm{mm}$ gap according to the procedure of Avena-Bustillos and others (2006).

\section{Desiccants}

Pollock skins were dried using the following desiccants: anhydrous calcium sulfate, 4 mesh (Hammond Drierite Co. Ltd., Xenia Ohio, U.S.A.), silicon dioxide (Spectrum Chemical Mfg. Corp., Gardena, Calif., U.S.A.), sodium chloride, rock salt (Morton Intl., Inc., Chicago Ill., U.S.A.), and calcium bentonite powder (Spectrum Chemical Mfg. Corp.). Descriptions of these adsorbent compounds are provided in Table 1 . Skins were placed approximately 2-cm apart and covered with the following quantities of desiccant per gram of skin: 22.0 g calcium sulfate, 44.1 g sodium chloride, $2.2 \mathrm{~g}$ silicon dioxide, or $8.8 \mathrm{~g}$ calcium bentonite. All treatment groups were then stored $\left(21^{\circ} \mathrm{C} ; 35 \% \mathrm{RH}\right)$ for $24 \mathrm{~h}$.

Air-dried skins were also placed approximately $2 \mathrm{~cm}$ apart and allowed to dry for $24 \mathrm{~h}$. After drying, all skins were weighed to determine moisture loss before vacuum packaging for storage prior to analysis. Water activities were measured with an AquaLab Water Activity Meter (Decagon Devices, Inc., Pullman, Wash., U.S.A.).

\section{Gel strength}

Gel strength was determined using $6.67 \%$ gels $(\mathrm{w} / \mathrm{w})$ at $2{ }^{\circ} \mathrm{C}$ on an Instron model 5500R Universal Testing Machine (Instron Corp.,
Canton, Mass., U.S.A.) using a $100 \mathrm{~N}$ load cell with the cross-head speed at $10 \mathrm{~mm} / \mathrm{min}$ and equipped with a $1.27-\mathrm{cm}$-dia. flat-faced cylindrical stainless steel plunger according to the procedure of Avena-Bustillos and others (2006).

\section{Gel-set temperature}

Viscoelastic studies were conducted using a Brookfield Digital Rheometer model DV-III (Brookfield Engineering Laboratories Inc., Middleboro, Mass., U.S.A.) equipped with a size 21 cylindrical spindle set for $10 \mathrm{rpm}$. Room temperature samples $(8.5 \mathrm{~g})$ were cooled from 25 to $2{ }^{\circ} \mathrm{C}$ at a rate of $4{ }^{\circ} \mathrm{C} / \mathrm{min}$ until the gel-set point was reached according to the procedure of Avena-Bustillos and others (2006).

\section{Water vapor permeability}

Water vapor permeabilities of gelatin films were determined according to ASTM E96-80 (ASTM 1989) with modifications by McHugh and others (1993).

\section{Tensile tests}

Gelatin film samples were prepared according to ASTM D882-02 (2002) procedures and conditioned at $30 \% \mathrm{RH}$. Samples were tested for maximum tensile strength, maximum percentage elongation at break (\%), and elastic modulus (or Young's modulus) using an Instron model 5500R Universal Testing Machine (Instron Corp.).

\section{SDS-polyacrylamide gel electrophoresis}

Molecular weight comparisons of gelatin samples were determined using NuPAGE Novex gels (10\% Bis-Tris) with NuPAGE MOPS SDS running buffer (Invitrogen Corp., Carlsbad, Calif., U.S.A.). Samples were diluted to a protein concentration of $0.7 \mu \mathrm{g}$ per lane before being denatured with NuPAGE LDS Sample Buffer and reduced with dithiothreitol at $70{ }^{\circ} \mathrm{C}$ for $10 \mathrm{~min}$. The gels were run (200 V, $50 \mathrm{~min}$ ) using an XCell SureLockTM electrophoresis unit (Invitrogen Life Technologies, Carlsbad, Calif., U.S.A.), and then stained with Invitrogen SimplyBlueTM according to the procedures provided by the manufacturer.

\section{Amino acid analysis}

Sixteen common amino acids plus hydroxyproline, hydroxylysine, and cysteine as cysteic acid were measured using a Hitachi L8900 Amino Acid Analyzer (Hitachi High-Technologies Corp., Pleasanton, Calif., U.S.A.) with postcolumn, ninhydrin derivatization (AAA Service Laboratory, Damascus, Oreg., U.S.A.).

\section{Statistics}

A one-way analysis of variance procedure was used with Statistica software, release 6 (StatSoft Inc., Tulsa, Okla., U.S.A.).

Table 1 - Description of nonhazardous naturally occurring adsorbent compounds evaluated for drying pollock skins.

\begin{tabular}{|c|c|c|c|}
\hline Desiccant & Mode of adsorption & Properties & References \\
\hline Calcium bentonite & $\begin{array}{l}\text { Aluminosilicate clay (montmorillonite) } \\
\text { with a layered structure that can } \\
\text { adsorb moisture }\end{array}$ & $\begin{array}{l}\text { Chemically inert, noncorrosive, adsorbs } \\
\text { up to } 28 \% \text { of its weight in water vapor } \\
\left(25^{\circ} \mathrm{C}, 80 \% \mathrm{RH}\right), \mathrm{GRAS}^{\mathrm{a}}\end{array}$ & $\begin{array}{l}\text { Graham and Bilanski 1986; Cases } \\
\text { and others } 1992\end{array}$ \\
\hline Calcium sulfate & $\begin{array}{l}\text { This mineral (gypsum) adsorbs water } \\
\text { onto the large surface area of its } \\
\text { pores and also binds water to form a } \\
\text { hemi-hydrate of calcium sulfate }\end{array}$ & $\begin{array}{l}\text { Compound is regenerable }\left(210^{\circ} \mathrm{C}, 1 \mathrm{~h}\right) \text {, } \\
\text { adsorbs up to } 9 \% \text { of its weight in water } \\
\text { vapor }\left(25^{\circ} \mathrm{C}, 75 \% \mathrm{RH}\right) \text {, GRAS, }{ }^{\mathrm{a}} \mathrm{ASP} \mathrm{SP}^{\mathrm{b}}\end{array}$ & Sabdo 2006; Hammond 2009 \\
\hline Sodium chloride & $\begin{array}{l}\text { This mineral (salt) adsorbs moisture } \\
\text { onto its surface }\end{array}$ & $\begin{array}{l}\text { Compound is corrosive and hygroscopic, } \\
\text { GRAS, }{ }^{a} \text { ASP }\end{array}$ & Lehto and Erling 2007 \\
\hline
\end{tabular}

aGRAS = generally recognized as safe (FDA 2009).

${ }^{b}$ ASP = fully up-to-date toxicology information has been sought (FDA 2009). 


\section{Results and Discussion}

\section{Moisture, water activity, gelatin ash content, and yields}

Pollock skins were dried for $24 \mathrm{~h}$ using 4 different moistureadsorbing agents: silicon dioxide, calcium bentonite, calcium sulfate, and sodium chloride. Results are listed in Table 2. The lowest moisture levels $(6.9 \%)$ were found in skins dried using calcium sulfate, whereas sodium chloride "salted" skins had the highest residual moisture (47\%). Calcium bentonite adsorbed moisture in quantities similar to the air-dried pollock skins, but significantly greater than silicon dioxide. Water activity $\left(A_{w}\right)$ values within each treatment group correlated with residual moisture levels, with calcium sulfate having the lowest $A_{w}(0.21)$ and sodium chloride the highest $(0.76)$. When gelatin was extracted from the dried pollock skins, recoveries generally ranged from $23 \%$ to $54 \%$, although skins treated with sodium chloride had significantly lower yields (11\%). These results suggest that the native conformation of collagen may have been disrupted in the presence of sodium chloride. Conditions that cause a protein to unfold can expose binding sites within the protein's core, thereby allowing new protein-protein interactions to occur and more water molecules to attach (McGuire and others 2000). Sodium chloride may have sufficiently masked the collagen's charges to sufficiently alter key functional properties such as solubility and gelatin yield.

Ash levels were quantified to determine if desiccants were being absorbed by the pollock skins during the drying process. Although the values ranged from $0.12 \%$ to $0.33 \%$ ash, no statistically significant differences were found (Table 2). This suggests that the decreased gelatin yields observed for sodium chloride, silicon dioxide, and calcium bentonite were likely not caused by permeation of salts into the skins, a condition that would have increased the ionic strength and affected protein conformation and solubility (Martinez-Alvarez and Gómez-Guillén 2006) during gelatin extraction.

\section{Physical properties of gelatin solutions}

Gelatin solutions displayed similar $\mathrm{pH}$ and clarities among treatments with the exception of reduced-clarity gelatin made from pollock skins that had been treated with sodium chloride (Table 3).
Gelatin is generally colorless and transparent (Food Chemicals Codex 1996), although the importance of clarity in a gel solution is highly dependent on the application for which the gel is intended.

When evaluating gelatin gels, perhaps the most important property is gel strength. In this study none of the desiccation treatments affected the gel strength of any of the pollock skin gelatins tested (Table 3). Gelation temperature is also an important parameter when evaluating gelatin, because the presence of salts can influence the setting time of gelatin gels (Sarabia and others 2000). There were no major differences in gelling temperature among treatments, nor were there differences in viscosity of the gelatin solutions. Cold-water fish-skin gelatins are known to exhibit increased viscosity at $5^{\circ} \mathrm{C}$ as the gelatin molecules begin to form gel networks during the cooling process (Avena-Bustillos and others 2006). Because viscosity is associated with improved functionality, gelatin films prepared from high-viscosity solutions are preferred and can command a higher price than films produced from lowviscosity gelatin solutions (Cole 2000).

\section{Water vapor permeability and mechanical properties of gelatin films}

When the gels were cast into films, water vapor permeability results were similar for all treatment groups (Table 4). Gelatin film strength was generally retained regardless of desiccant type.

Table 4- Barrier and mechanical properties of gelatin films prepared from pollock skins that were treated with different drying agents to remove moisture prior to gelatin production.

\begin{tabular}{lcc}
\hline & $\begin{array}{c}\text { Water vapor } \\
\text { permeability at } 90-0 \% \\
\text { DH gradient }\end{array}$ & \\
\hline Desiccant & $\left.\mathbf{R} \cdot \mathbf{m m}) /\left(\mathbf{k P a} \cdot \mathbf{h} \cdot \mathbf{m}^{2}\right)\right]$ & $\begin{array}{c}\text { \% Elongation } \\
\text { at } \mathbf{7 0} \% \mathbf{R H}\end{array}$ \\
\hline Calcium sulfate & $0.64 \pm 0.08^{\mathrm{NS}}$ & $3.7 \pm 0.4^{\mathrm{NS}}$ \\
Sodium chloride & $0.70 \pm 0.10$ & $3.3 \pm 0.4$ \\
Silicon dioxide & $0.67 \pm 0.10$ & $3.5 \pm 0.3$ \\
Calcium bentonite & $0.70 \pm 0.10$ & $3.5 \pm 1.0$ \\
Air-dried & $0.64 \pm 0.14$ & $3.1 \pm 0.8$ \\
\hline
\end{tabular}

NS signifies that no significant differences were found.

Table 2- Effectiveness of chemical desiccants for removal of moisture from pollock skins with ash uptake during desiccation and the resultant gelatin yields.

\begin{tabular}{|c|c|c|c|c|}
\hline Desiccant & $\%$ Moisture & Water activity & $\%$ Ash & Gelatin yield \\
\hline $\begin{array}{l}\text { Calcium sulfate } \\
\text { Sodium chloride } \\
\text { Silicon dioxide } \\
\text { Calcium bentonite } \\
\text { Air-dried } \\
\text { Fresh (Control) }\end{array}$ & $\begin{array}{r}6.9 \pm 0.5^{\mathrm{a}} \\
47.3 \pm 0.7^{\mathrm{d}} \\
24.1 \pm 0.6^{\mathrm{c}} \\
17.6 \pm 0.8^{\mathrm{b}} \\
13.6 \pm 0.4^{\mathrm{b}} \\
70.0 \pm 1.0^{\mathrm{e}}\end{array}$ & $\begin{array}{l}0.21 \pm 0.02^{\mathrm{a}} \\
0.76 \pm 0.00^{\mathrm{d}} \\
0.74 \pm 0.01^{\mathrm{d}} \\
0.53 \pm 0.03^{\mathrm{c}} \\
0.38 \pm 0.01^{\mathrm{b}} \\
1.00 \pm 0.00^{\mathrm{e}}\end{array}$ & $\begin{array}{l}0.17 \pm 0.04^{\mathrm{ab}} \\
0.19 \pm 0.02^{\mathrm{ab}} \\
0.33 \pm 0.03^{\mathrm{b}} \\
0.12 \pm 0.03^{\mathrm{ab}} \\
0.21 \pm 0.04^{\mathrm{ab}} \\
0.07 \pm 0.01^{\mathrm{a}}\end{array}$ & $\begin{array}{l}52.9 \pm 3.3^{\mathrm{cd}} \\
11.3 \pm 2.4^{\mathrm{a}} \\
37.0 \pm 2.6^{\mathrm{bc}} \\
23.9 \pm 1.0^{\mathrm{ab}} \\
54.0 \pm 5.8^{\mathrm{cd}} \\
58.7 \pm 7.5^{\mathrm{d}}\end{array}$ \\
\hline
\end{tabular}

Numbers represent mean values and standard errors after desiccation $\left(24 \mathrm{~h}, 21^{\circ} \mathrm{C}, 35 \% \mathrm{RH}\right)$.

Superscripted letters represent significant differences $(p<0.05)$ within columns only.

Table 3- Properties of gels prepared from pollock skins that were treated with different drying agents to remove moisture prior to gelatin production.

\begin{tabular}{|c|c|c|c|c|}
\hline Desiccant & $\begin{array}{l}\text { Gel pH } \\
\left(21^{\circ} \mathrm{C}\right)\end{array}$ & $\begin{array}{c}\% \text { Transmittance } \\
\left(600 \mathrm{~nm}, 21^{\circ} \mathrm{C}\right)\end{array}$ & $\begin{array}{l}\text { Gel strength } \\
\left(\mathrm{N} \text { at } 2{ }^{\circ} \mathrm{C}\right)\end{array}$ & $\begin{array}{l}\text { Temperature of } \\
\text { gelation }\left({ }^{\circ} \mathbf{C}\right)\end{array}$ \\
\hline $\begin{array}{l}\text { Air-dried } \\
\text { Calcium sulfate } \\
\text { Sodium chloride } \\
\text { Silicon dioxide } \\
\text { Calcium bentonite }\end{array}$ & $\begin{array}{l}2.6 \pm 0.02^{N S} \\
2.6 \pm 0.04 \\
2.5 \pm 0.04 \\
2.6 \pm 0.11 \\
2.7 \pm 0.05\end{array}$ & $\begin{array}{l}97.0^{b} \\
96.7^{b} \\
91.2^{a} \\
97.6^{b} \\
97.7^{b}\end{array}$ & $\begin{array}{l}45.6 \pm 15.6^{\mathrm{NS}} \\
55.5 \pm 9.0 \\
58.6 \pm 10.7 \\
53.1 \pm 5.4 \\
54.9 \pm 6.8\end{array}$ & $\begin{array}{l}3.0 \pm 0.3^{\mathrm{a}} \\
4.9 \pm 0.3^{\mathrm{b}} \\
4.6 \pm 0.7^{\mathrm{b}} \\
3.5 \pm 0.2^{\mathrm{a}} \\
3.3 \pm 1.6^{\mathrm{ab}}\end{array}$ \\
\hline
\end{tabular}

Superscripted letters represent significant differences $(p<0.05)$ within columns only.

NS signifies that no significant differences were found. 
Table 5 - Amino acid profile of pollock skin gelatin after skins were dehydrated with select desiccants.

\begin{tabular}{|c|c|c|c|c|c|}
\hline \multicolumn{6}{|c|}{ Drying and desiccant type } \\
\hline Amino acid & $\begin{array}{c}\text { Air-dried } \\
\left(21^{\circ} \mathrm{C} ; 42 \% \mathrm{RH}\right)\end{array}$ & $\begin{array}{l}\text { Calcium } \\
\text { sulfate }\end{array}$ & $\begin{array}{c}\text { Calcium } \\
\text { bentonite }\end{array}$ & $\begin{array}{l}\text { Sodium } \\
\text { chloride }\end{array}$ & $\begin{array}{l}\text { Silicon } \\
\text { dioxide }\end{array}$ \\
\hline Alanine & 50.70 & 47.78 & 42.08 & 40.88 & 38.25 \\
\hline Aspartic acid & 40.84 & 38.55 & 33.83 & 32.82 & 30.81 \\
\hline Glutamic acid & 63.51 & 59.58 & 52.40 & 50.78 & 47.38 \\
\hline Glycine & 137.60 & 129.83 & 113.99 & 110.58 & 103.78 \\
\hline Hydroxyproline & 40.22 & 38.02 & 34.30 & 33.08 & 30.75 \\
\hline Isoleucine & 9.16 & 8.61 & 7.47 & 7.32 & 6.88 \\
\hline Leucine & 16.59 & 15.65 & 13.68 & 13.35 & 12.54 \\
\hline Lysine & 23.97 & 22.69 & 19.76 & 19.11 & 18.11 \\
\hline Methionine & 14.62 & 13.80 & 12.12 & 11.79 & 10.93 \\
\hline Phenylalanine & 12.99 & 12.29 & 10.89 & 10.68 & 10.05 \\
\hline Proline & 65.48 & 61.87 & 54.28 & 52.79 & 49.63 \\
\hline
\end{tabular}

Data are expressed as mg of amino acid per gram of protein.

Only those amino acids indicated were determined.

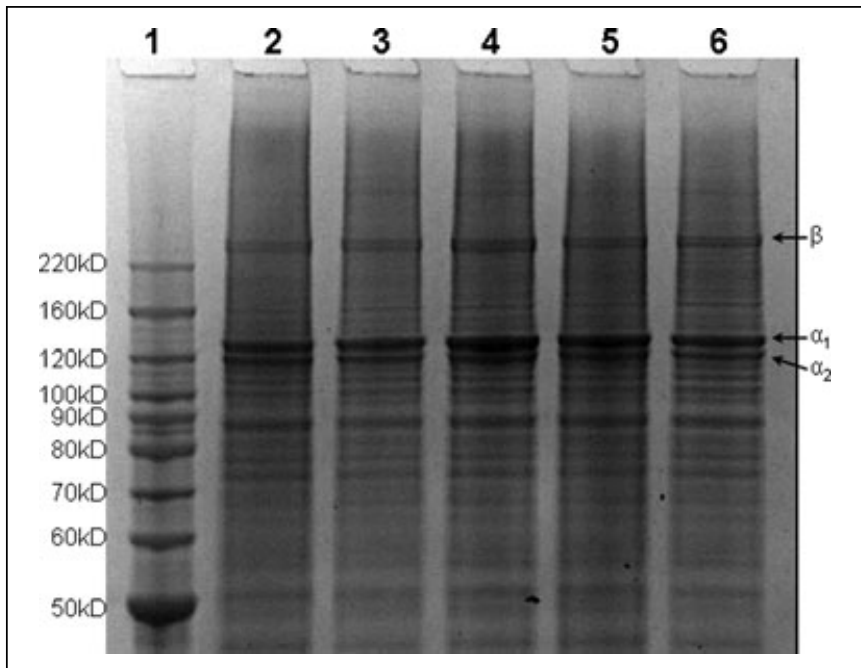

Figure 1-SDS-polyacrylamide gel electrophoresis of gelatins prepared from pollock skins after dehydration with desiccants for 24 h (lane 1, marker; lane 2, air dried; lane 3, calcium sulfate; lane 4, sodium chloride; lane 5, silicon dioxide; lane 6, calcium bentonite). Alpha and beta gelatin bands are labeled.

Elasticity was actually found to be superior in gelatin films prepared from calcium sulfate and calcium bentonite treated pollock skins, possibly due to calcium cross-linking (Table 4). When evaluating gelatin films for water vapor permeability and tensile strength it is important that the film thickness be comparable among samples. In this study, there were no statistically significant differences in film thickness among any of the samples tested.

\section{Molecular weight and amino acid content of gelatins}

When gelatin films are produced, their mechanical and barrier properties are important factors. These properties are controlled at the molecular level based on the distribution of amino acids. For example, an increased quantity of proline and hydroxyproline residues are known to stabilize the triple-helix conformation that is responsible for forming a strong gel network (Gómez-Guillén and others 2002).
The molecular weight distributions for each gelatin treatment are shown in Figure 1. No differences were apparent among treatment groups, suggesting that the desiccating agents used to reduce the moisture content of pollock skins had no effect on the collagen structure. The original collagen $\alpha 1$ and $\alpha 2$ chains are the major contributors of gel strength (Heidemann and others 1988) and can covalently cross-link to form $\beta$ chains in gelatin (Balian and Bowes 1977).

Cold-water fish-skin gelatins such as those extracted from pollock are known to have significantly less hydroxyproline, proline, valine, and leucine than their mammalian counterparts (AvenaBustillos and others 2006). In this study, the quantity of hydroxyproline and proline appeared to be substantially lower for sodium chloride and silicon dioxide treatments (Table 5), although no significant differences were found and the lower quantities were not reflected in gel strength values (Table 3 ).

\section{Conclusion}

The use of regenerable desiccants offers many advantages 1 for preserving perishable commodities. By stabilizing pollock skins through reduction of water weight, the transportation costs can be decreased during shipment to a gelatin-processing facility.

\section{Acknowledgments}

This research is being performed as part of a larger USDA Agricultural Research Service project designed to convert underutilized Alaska fish by-products into value-added ingredients and products [CRIS \#5341 31510003 00D].

\section{References}

Avena-Bustillos RJ, Olsen CW, Olson DA, Chiou B, Yee E, Bechtel PJ, McHugh TH. 2006. Water vapor permeability of mammalian and fish gelatin films. J Food Sci 71(6):E202-E207.

ASTM Standards. 1989. E96-80: Standard test methods for water vapor transmission of materials. West Conshohocken, Pa., USA: American Society for Testing and Materials.

ASTM Standards. 2002. D882-02: Standard test method for tensile properties of thin plastic sheeting. West Conshohocken, Pa., USA: American Society for Testing and Materials.

Balian G, Bowes JH. 1977. The structure and properties of collagen. In: Ward AG, Courts A, editors. The science and technology of gelatin. London: Academic Press. p 1-31.

Bower CK, Avena-Bustillos RD, Olsen CW, McHugh TH, Bechtel PJ. 2006. Characterization of fish skin gelatin gels and films containing the antimicrobial enzyme lysozyme. J Food Sci 71(5):141-5. 
Cases JM, Berend I, Besson G, Francois M, Uriot JP, Thomas F, Poirier JE. 1992. Mechanism of adsorption and desorption of water vapor by homoionic montmorillonite. 1. The sodium-exchanged form. Langmuir 8(11):2730-9.

Chiou BS, Avena-Bustillos RJ, Bechtel PJ, Jafri H, Narayan R, Imam SH, Glenn GM, Orts WJ. 2008. Cold water fish gelatin films: effects of cross-linking on thermal, mechanical, barrier, and biodegradation properties. Eur Polym J 44(11):3748-53.

Cole B. 2000. Gelatin. In: Francis FJ, editor. Encyclopedia of food science and technology. New York: John Wiley \& Sons. p 1183-8.

Dapkevicius MLNE, Nout MJR, Rombouts FM, Houben JH, Wymenga W. 2000. Biogenic amine formation and degradation by potential fish silage starter microorganisms. Int J Food Microbiol 57:107-14.

FDA (U.S. Food and Drug Administration). [Internet]. Silver Spring, MD. [Updated 2009 Nov 9]. Available from: http://www.accessdata.fda.gov/scripts/fcn/ fcnNavigation.cfm?rpt=eafusListing.

Food Chemicals Codex. 1996. Food and Nutrition Board, Natl. Academy of Sciences. 1996. Food chemicals codex. 4th ed. Washington, D.C.: Natl. Academy Press.

Fraioli AV. 1987. Mass transfer mechanisms for water adsorbed on silica gel. Am Soc Mech Eng, Solar Energy Div. (Publication) SED 4:23-29.

Giménez B, Gómez-Guillén MC, Montero P. 2005. Storage of dried fish skins on quality characteristics of extracted gelatin. Food Hydrocolloids 19:958-63.

Gokoglu N, Yerlikaya P, Cengiz E. 2003. Biogenic amines formation in sardine marinade during refrigerated storage. J Food Biochem 27(5):435-47.

Gómez-Guillén MC, Turnay J, Fernandez-Diaz MD, Ulmo N, Lizarbe MA, Montero P. 2002. Structural and physical properties of gelatin extracted from different marine species: a comparative study. Food Hydrocolloids 16:25-34.

Gómez-Guillén MC, Pérez-Mateos M, Gómez-Estaca J, López-Caballero E, Giménez B, Montero P. 2009. Fish gelatin: a renewable material for developing active biodegradable films. Trends Food Sci Technol 20:3-16.

Graham VA, Bilanski WK. 1986. Simulation of grain drying in intimate contact with adsorbents. Trans ASAE, Am Soc Agric Engr 29(6):1776-83.

Hammond WA. 2009. Technical data - regeneration of Drierite desiccants. W.A.
Hammond Drierite Co. Ltd. Available from: http://www.drierite.com/catalog3/ page19b.cfm. Accessed Aug 1, 2009.

Heidemann E, Peng B, Neiss HG, Moldehn R. 1988. Proceedings of the 5th IAG Conference: Photographic Gelatin. In: Ammann-Brass H, Pouradier J, editors. Photogelatine, Fribourg, Switzerland: Intl. Arbeitsgem.

Karim AA, Bhat R. 2009. Fish gelatin: properties, challenges, and prospects as an alternative to mammalian gelatins. Food Hydrocolloids 23:563-76.

Lehto V-P, Erling I. 2007. An effective desiccant system to regulate the humidity inside the chambers of the solid dosage forms. Drug Develop Ind Pharm 33(11):12339

Martinez-Alvarez O, Gómez-Guillén MC. 2006. Effect of brine salting at different pHs on the functional properties of cod muscle proteins after subsequent dry salting. Food Chem 94:123-9.

McGuire J, Bower CK, Bothwell MK. 2000. On the molecular origins of protein structure and function at interfaces. Aust J Dairy Technol 55(2):65-70.

McHugh TH, Avena-Bustillos R, Krochta JM. 1993. Hydrophilic edible films: modified procedure for water vapor permeability and explanation of thickness effects. J Food Sci 58(4):899-903.

Reza MS, Bapary MAJ, Islam MN, Kamal M. 2009. Optimization of marine fish drying using solar tunnel dryer. J Food Proc Preserv 33(1):47-59.

Sabdo R. 2006. Choosing the right sorbent for electronics applications. Adv Packag 15(9):18.

Sarabia AI, Gómez-Guillén MC, Montero P. 2000. The effect of added salts on the viscoelastic properties of fish skin gelatin. Food Chem 70(1):71-76.

Sikorski ZE, Kałodziejska I. 2002. Microbial risks in mild hot smoking of fish. CRC Crit Rev Food Sci Nutr 42(1):35-51.

Villota R, Hawkes JG 1986. Food applications and the toxicological and nutritional implications of amorphous silicon dioxide. CRC Crit Rev Food Sci Nutr 23(4):289-321.

Wang D, Tang J, Correia LR. 2000. Salt diffusivities and salt diffusion in farmed Atlantic salmon muscle as influenced by rigor. J Food Engr 43(2):115-23. 